СЕМЕНЕНКО О. І., к.т.н., доцент,

СУПРУН О. Д., к.Т.Н., доцент,

СЕМЕНЕНКО Ю. О., к.Т.н., старший викладач,

ТКАЧЕНКО М. П., магістрант (Український державний університет залізничного транспорту)

\title{
Дослідження ефективності роботи згладжувальних пристроїв перетворювальних агрегатів тягових підстанцій постійного струму
}

Розглянуто шляхи покращення якості енергї живлення електричного рухомого складу постійного струму. Проаналізовано роботу згладжувальних пристроїв, які використовуються на тягових підстанціях для придушення змінної складової вихідної напруги. Експериментально підтверджено, щуо при несиметрї вхідної напруги перетворювальним агрегатом у тягову мережу генеруються не тільки канонічні гармоніки напруги з частотами основної та вищих гармонік, а й неканонічні гармоніки випрямленої напруги. Для їх придушення необхідні дуже складні, громіздкі згладжувальні пристрої, які ще й не є ефективними на низьких частотах.

Ключові слова: тягова підстанція, пасивний фільтр, гармонічні складові, пульсність випрямляча, коефіцієнт згладжування, частотні характеристики.

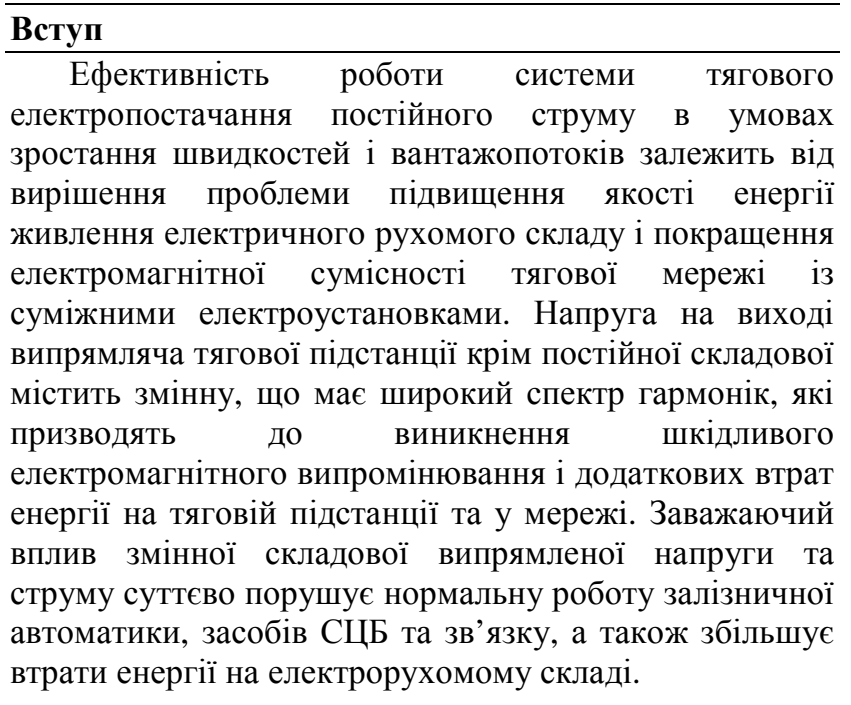

\begin{tabular}{l}
\hline Аналіз останніх досліджень та публікацій \\
\hline Для підвищення якості електричної енергї і \\
поліпшення електромагнітної сумісності системи \\
тягового електропостачання постійного струму із \\
суміжними електроустановками використовуються \\
згладжувальні пристрої, у ролі яких традиційно \\
застосовують пасивні фільтри [1-3]. Їх застосування на \\
тягових підстанціях постійного струму недостатньо \\
ефективне при великих навантаженнях, оскільки у \\
таких умовах істотно підвищується рівень гармонік \\
вихідної напруги перетворювального агрегату [1-3]. \\
При цьому залишається невирішеною проблема \\
компенсації низькочастотних неканонічних гармонік
\end{tabular} напруги і струму у тяговій мережі частотою нижче частоти основної гармоніки випрямленої напруги.

\section{Визначення мети та задачі досліджень}

Метою цієї статті є дослідження ефективності роботи існуючих схем згладжувальних пристроїв на виході тягової підстанції постійного струму та визначення шляхів покращення показників їх роботи.

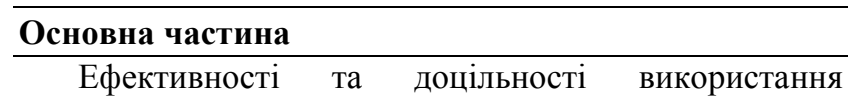
згладжувальних пристроїв на тягових підстанціях постійного струму присвячений цілий ряд наукових праць [1, 5-9]. 3 урахуванням зростаючих вимог до якості електричної енергії згідно з [2,4] на залізницях мають застосовуватися дволанкові фільтри. Однак на практиці застосовуються як одноланкові, так і дволанкові пасивні фільтри.

Найбільш часто 3 одноланкових згладжувальних пристроїв застосовується типовий одноланковий пасивний фільтр та пасивний фільтр для дванадцатипульсних випрямлячів [2]. 3 дволанкових це пасивний фільтр Західносибірської залізниці (3С3), типовий дволанковий пасивний фільтр і пасивний фільтр ЦНДІ МШС, які розроблені ще в радянські роки у зазначених у назві залізничних структурних підрозділах. При проведенні науково-дослідної роботи «Перевірка електромагнітної сумісності тягової підстанції з контактною мережею» на трьох дистанціях електропостачання (ЕЧ-2, ЕЧ-6 та ЕЧ-7) Південної залізниці ПАТ «Укрзалізниця» було встановлено, що 3

() О. І. Семененко, О. Д. Супрун, Ю. О. Семененко, М. П. Ткаченко, 2018 
вісімнадцяти тягових підстанцій на восьми застосована схема одноланкового пасивного фільтра, ще на восьми - схема дволанкового пасивного фільтра та на двох схема ЦНДІ МШС.

При оцінці згладжувальних пристроїв відповідно до [2] критерієм, що визначає якість роботи пасивного фільтра, є коефіцієнт згладжування. Він визначається зі співвідношення еквівалентної заважаючої напруги на вході фільтра до її величини на виході фільтра

$k_{\text {згл }}=\frac{U_{\text {вх.3 }}}{U_{\text {вих.3 }}}$.

Величина коефіцієнта згладжування відповідно до [4] повинна бути в межах

$25 \leq k_{\text {згл }} \leq 50$.

Як відомо, максимальну ефективність пасивних фільтрів вдається отримати у діапазоні частот

$m \cdot f_{0} \leq f_{k} \leq(4 . .6) m \cdot f_{0}$,

де $f_{0}$ та $f_{k}$ - частоти мережі живлення та $k$-ї гармоніки відповідно;

$m$ - пульсність випрямляча.

Підвищення ефективності пасивної фільтрації гармонік у діапазоні частот (3) реалізується за рахунок застосування багатоланкових структур з резонансними (режекторними) ланками. Такі фільтри, при кількості ланок більше двох, досить складні за конструкцією та в експлуатації, на їх характеристики впливають параметри навантаження, що має принципове значення для систем тягового електропостачання. Ефективність фільтрів $з$ режекторними ланками сильно залежить від добротності останніх, що робить їх чутливими до змін частоти мережі та змін характеристик елементів, що входять до їх складу, які відбуваються з плином часу.

Для аналізу роботи згладжувальних пристроїв була запропонована еквівалентна схема одноланкового пасивного фільтра, яка наведена на рис. 1.

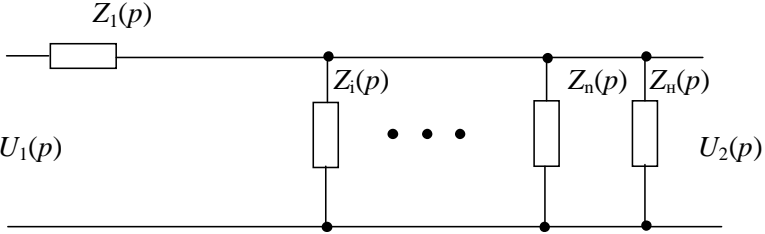

Рис. 1. Еквівалентна схема одноланкового пасивного фільтра тягової підстанції

Структурно одноланковий пасивний фільтр тягової підстанції містить поздовжний ланцюг, у який входить реактор 3 опором $Z_{1}(p)$, і поперечні ланцюги $Z_{i}(p)$. До вихідних ланок фільтра під'єднане навантаження $Z_{\mathrm{H}}(p)$.

Спрямований граф, який встановлює зв'язок між вхідною і вихідною напругами фільтра, наведено на рис. 2.

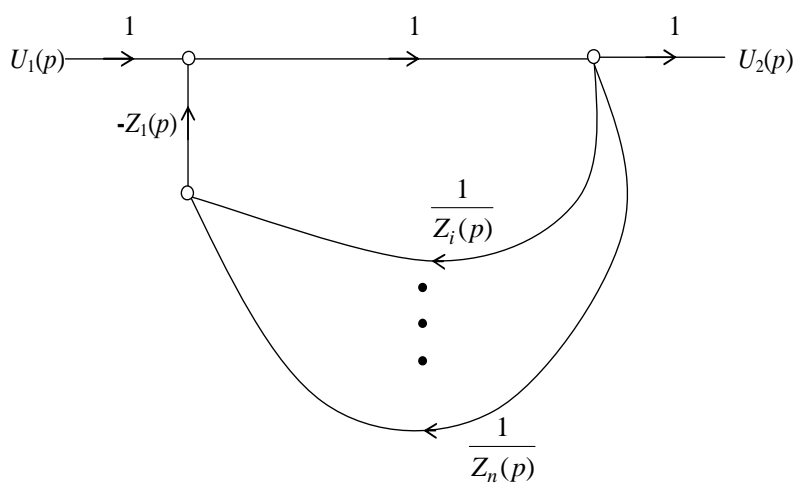

Рис. 2. Спрямований граф одноланкового пасивного фільтра з режекторними ланками

Передавальна функція одноланкового пасивного фільтра 3 режекторними ланками визначається рівнянням

$$
H(p)=\frac{1}{1+Z_{1}(p)\left[\frac{1}{Z_{i}(p)}+\ldots+\frac{1}{Z_{n}(p)}+\frac{1}{Z_{H}(p)}\right]}
$$

де $Z_{1}(p)=R_{1}+L_{1} p$ - опір поздовжньої ланки;

$$
Z_{i}(p)=R_{i}+L_{i} p+\frac{1}{p C_{i}}-\text { опір } i \text {-ї поперечної }
$$
ланки;

$$
Z_{н}(p)=R_{\mu}+L_{н} p-\text { опір навантаження. }
$$

Частотна передавальна функція одноланкового пасивного фільтра з режекторними ланками

$$
H(j \omega)=\left\{1-\sum_{i=1}^{n}\left[\frac{\omega^{2} L_{1} C_{i}\left(1-\omega^{2} L_{i} C_{i}\right)}{\left(1-\omega^{2} L_{i} C_{i}\right)^{2}+\omega^{2} R_{i}^{2} C_{i}^{2}}-j \frac{\omega^{2} L_{1} C_{i} R_{i}}{\left(1-\omega^{2} L_{i} C_{i}\right)^{2}+\omega^{2} R_{i}^{2} C_{i}^{2}}\right]+j \frac{\omega L_{1}}{R_{H}+j \omega L_{\mathrm{H}}}\right\}^{-1} .
$$


Логарифмічна характеристика фільтра визначається виразом

$$
K(\omega)=20 \lg \sqrt{\frac{1}{\operatorname{Re}[H(j \omega)]^{2}+\operatorname{Im}[H(j \omega)]^{2}}} .
$$

Як приклад наведемо логарифмічні амплітудночастотні характеристики одноланкового пасивного

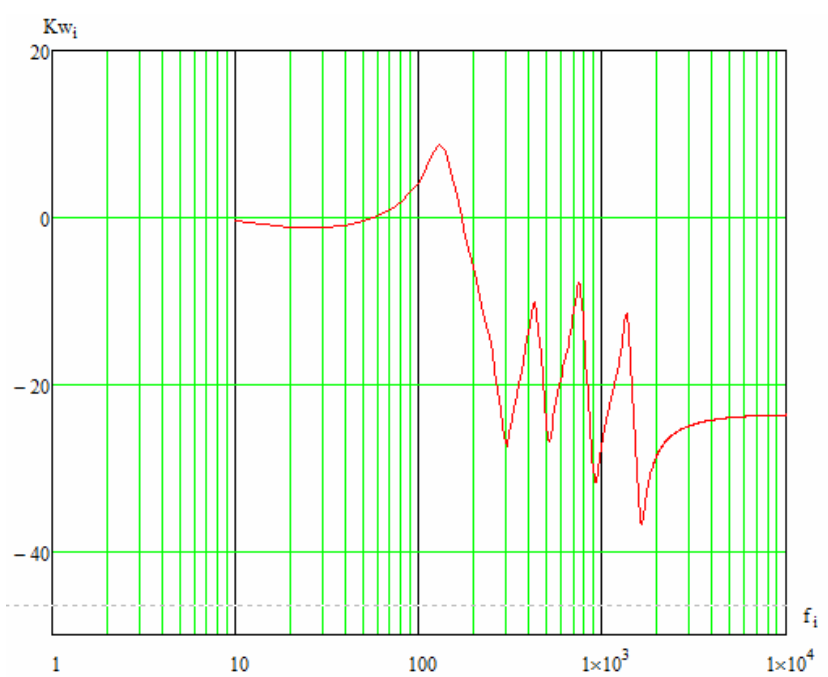

$a$ фільтра, що використовується як основний згладжувальний пристрій на тяговій підстанції ЕЧЕ-8. Характеристики, зображені на рис. 3, $\epsilon$ розрахунковими, але отримані вони при використанні реальних значень параметрів елементів фільтра в умовах різних значень активно-індуктивного навантаження.

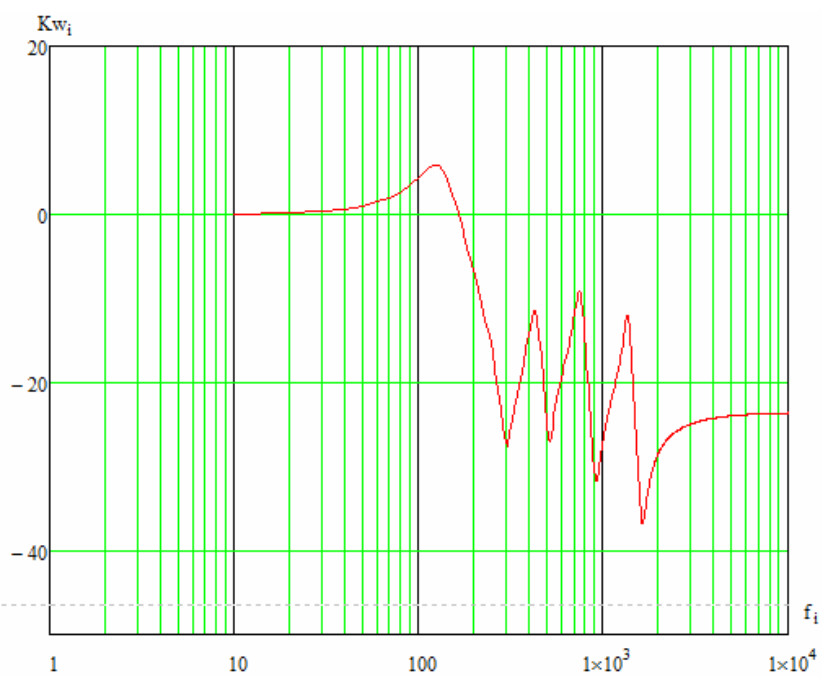

6

Рис. 3. Амлітудно-частотні характеристики фільтра при активно-індуктивному навантаженні:

$$
a-R_{\mathrm{H}}=1 \mathrm{OM}, L_{\mathrm{H}}=0,005 \Gamma \mathrm{H} ; \sigma-R_{\mathrm{H}}=10 \text { ОМ, } L_{\mathrm{H}}=0,005 \Gamma \mathrm{H}
$$

Еквівалентна схема для аналізу роботи дволанкового пасивного фільтра тягової підстанції постійного струму наведена на рис. 4.

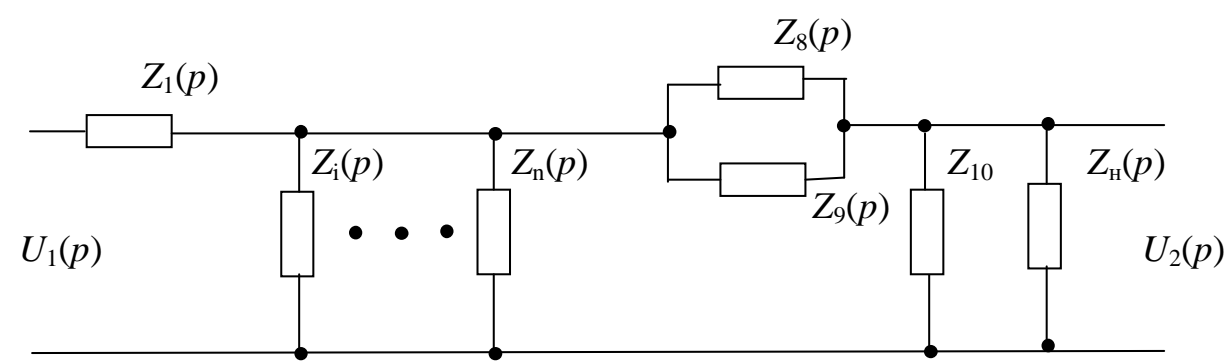

Рис. 4. Еквівалентна схема дволанкового пасивного фільтра тягової підстанції

Спрямований граф, який установлює зв'язок між вхідною $U_{1}(p)$ та вихідною $U_{2}(p)$ напругами дволанкового пасивного фільтра тягової підстанції постійного струму, наведено на рис. 5. 


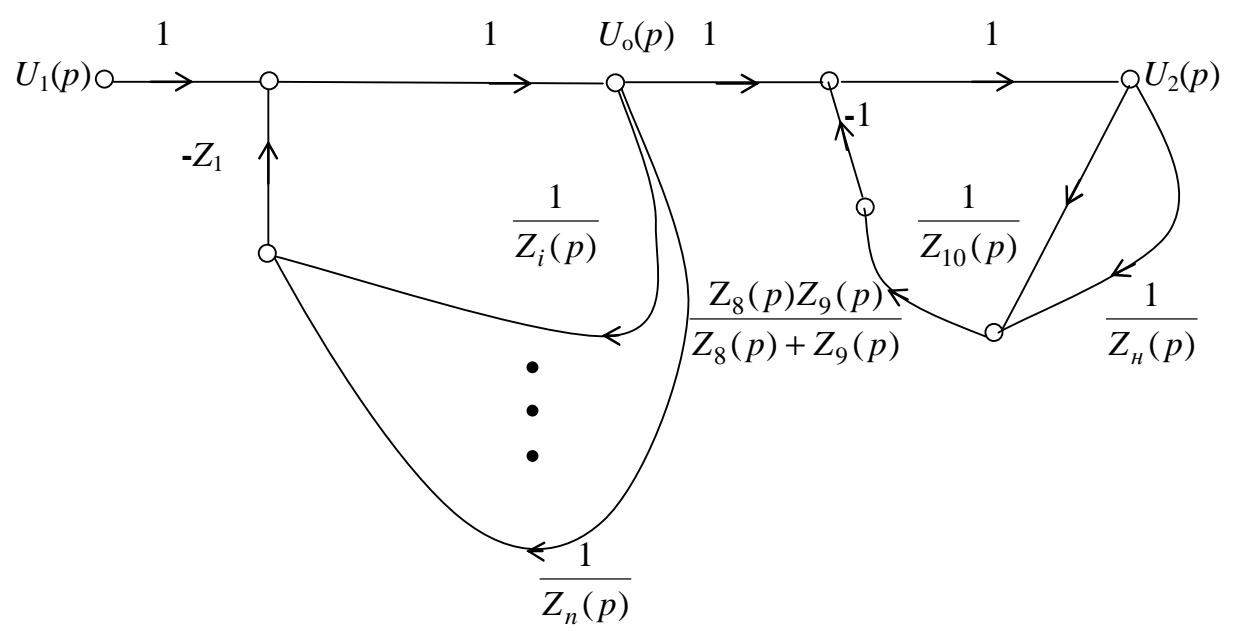

Рис. 5. Спрямований граф дволанкового пасивного фільтра з режекторними ланками

Частотна передавальна функція фільтра у комплексному виді запису:

$$
\begin{aligned}
H(j \omega)= & \left\{1-\sum_{i=1}^{n}\left[\frac{\omega^{2} L_{1} C_{i}\left(1-\omega^{2} L_{i} C_{i}\right)}{\left(1-\omega^{2} L_{i} C_{i}\right)^{2}+\omega^{2} R_{i}^{2} C_{i}^{2}}-j \frac{\omega^{2} L_{1} C_{i} R_{i}}{\left(1-\omega^{2} L_{i} C_{i}\right)^{2}+\omega^{2} R_{i}^{2} C_{i}^{2}}\right]-\right. \\
& \left.-\frac{a(\omega) d(\omega)-c(\omega) b(\omega)}{c^{2}(\omega)+d^{2}(\omega)}-j \frac{a(\omega) c(\omega)+b(\omega) d(\omega)}{c^{2}(\omega)+d^{2}(\omega)}\right\}^{-1}
\end{aligned}
$$

де $a(\omega)=\omega\left[L_{8}\left(1-\omega^{2} L_{9} C_{7}\right)\left(1-\omega^{2} L_{H} \mathrm{C}_{8}\right)-\omega^{2} R_{7}^{2} L_{8} C_{7} C_{8}\right]$

$$
\begin{aligned}
& b(\omega)=\omega^{2} R_{7} L_{8} C_{7}\left(2-\omega^{2} L_{\mathrm{H}} C_{8}-\omega^{2} L_{9} C_{9}\right) ; \\
& c(\omega)=R_{\mathrm{H}}\left[1-\omega^{2} C_{7}\left(L_{8}-L_{9}\right)\right]-\omega^{2} R_{7} L_{\mathrm{H}} C_{7} ; \\
& d(\omega)=\omega\left\{R_{\mathrm{H}} R_{7} C_{7}+L_{\mathrm{H}}\left[1-\omega^{2} C_{7}\left(L_{8}+L_{9}\right]\right\} .\right.
\end{aligned}
$$

Логарифмічна амплітудно-частотна характеристика:

$$
\begin{aligned}
& K(\omega)=20 \lg \frac{1}{\sqrt{U_{3}^{2}(\omega)+V_{3}^{2}(\omega)}}, \\
& \text { де } U_{3}(\omega)=1-\left[\sum_{i=1}^{n} \frac{\omega^{2} L_{1} C_{i}\left(1-\omega^{2} L_{i} C_{i}\right)}{\left(1-\omega^{2} L_{i} C_{i}\right)^{2}+\omega^{2} R_{i}^{2} C_{i}^{2}}+\frac{a(\omega) d(\omega)-c(\omega) b(\omega)}{c^{2}(\omega)+d^{2}(\omega)}\right] \\
& V_{3}(\omega)=\sum_{i=1}^{n} \frac{\omega^{2} L_{1} C_{i} R_{i}}{\left(1-\omega^{2} L_{i} C_{i}\right)^{2}+\omega^{2} R_{i}^{2} C_{i}^{2}}+\frac{a(\omega) c(\omega)+b(\omega) d(\omega)}{c^{2}(\omega)+d^{2}(\omega)} .
\end{aligned}
$$

Як приклад побудована амплітудно-частотна характеристика дволанкового пасивного згладжувального пристрою, що застосовується на тяговій підстанції ЕЧЕ-42. Характеристики фільтра, які зображені на рис. 6, були отримані при різних значеннях активно-індуктивного навантаження. 

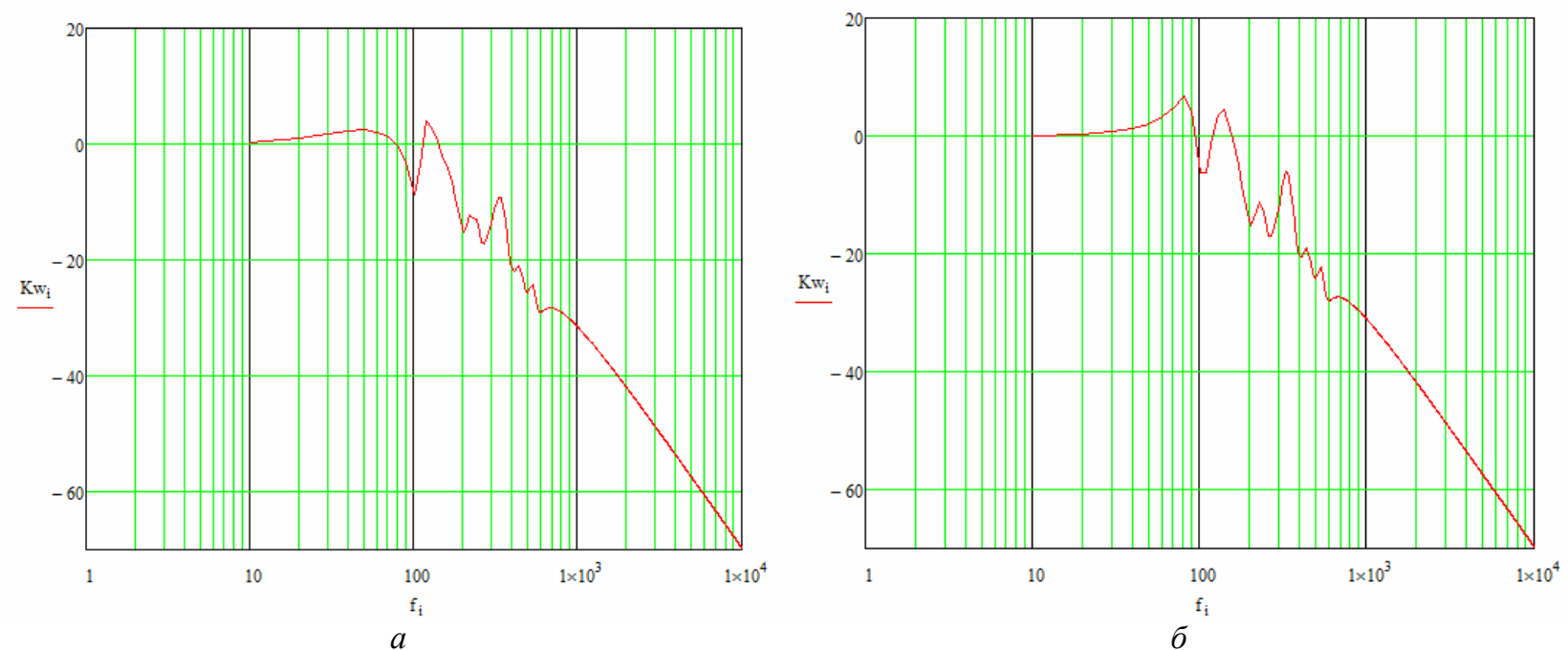

Рис. 6. Амлітудно-частотні характеристики фільтра при активно-індуктивному навантаженні:

$$
a-R_{\mathrm{H}}=1 \mathrm{OM}, L_{\mathrm{H}}=0,005 \Gamma \mathrm{H} ; \sigma-R_{\mathrm{H}}=10 \mathrm{OM}, L_{\mathrm{H}}=0,005 \Gamma_{\mathrm{H}}
$$

Для перевірки результатів аналітичних досліджень ефективності роботи згладжувальних пристроїв тягових підстанцій постійного струму розглянемо розроблені в середовищі MATLAB \& Simulink їx імітаційні комп'ютерні моделі. Параметри згладжувальних пристроїв обрані згідно із значеннями, отриманими при обстеженні тягових підстанцій раніше зазначених дистанцій електропостачання при виконанні НДР.

Дослідження схеми одноланкового пасивного фільтра (імітаційна комп'ютерна модель якого подана на рис. 7) проводимо при активно-індуктивному навантаженні та несиметричній вхідній трифазній напрузі, яка згідно з [2, 4] не повинна перевищувати значення $2 \%$.

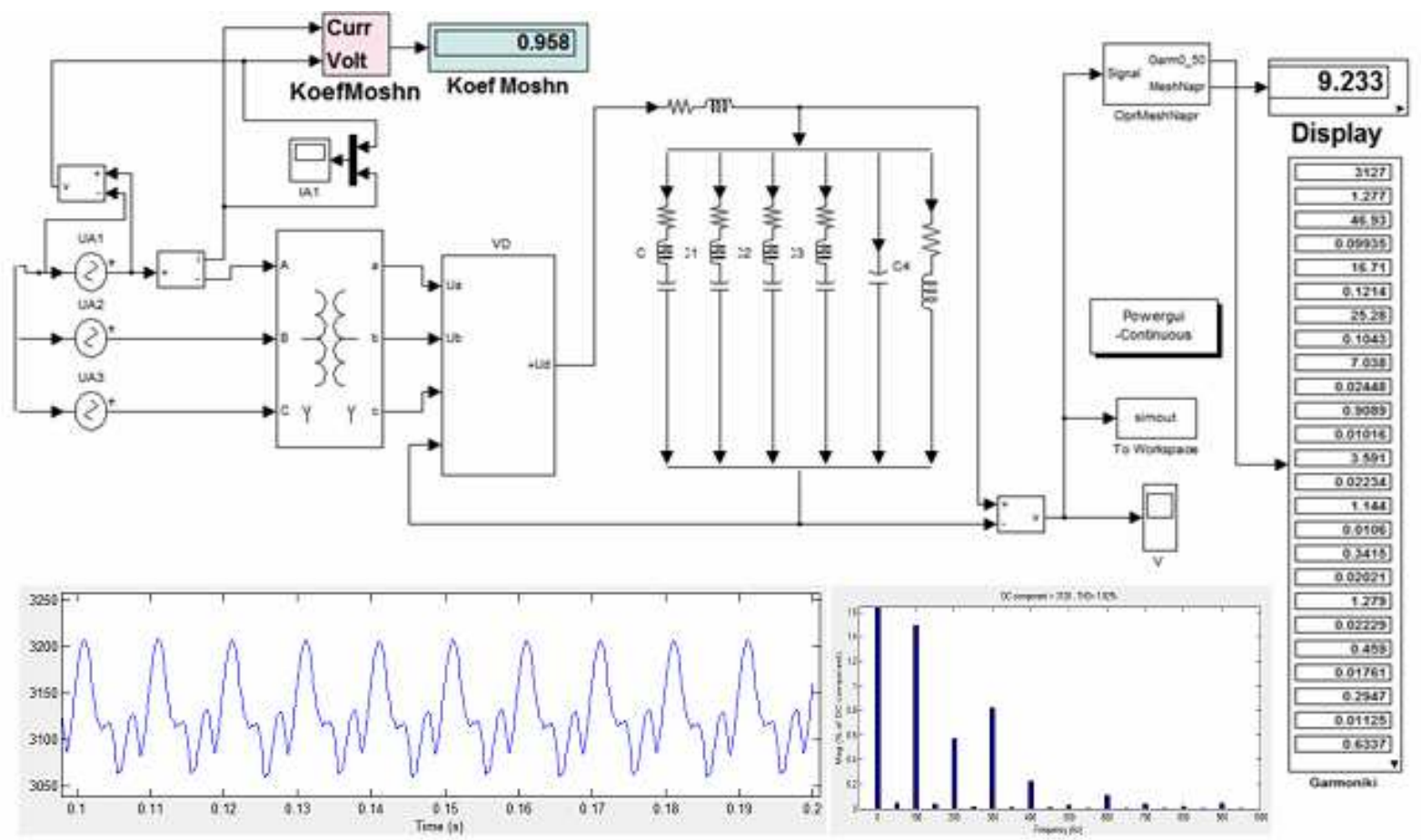

Рис. 7. Імітаційна комп'ютерна модель одноланкового пасивного фільтра, осцилограма вихідної напруги та діаграма спектрального складу 
3 рис. 7 видно, що амплітуди неканонічних гармонік вихідної напруги частотами 100 та 200 Гц становлять 1,52 та $0,6 \%$ відносно постійної складової, тоді як амплітуда основної гармонічної складової, частота якої для шестипульсного випрямляча становить 300 Гц, дорівнює $0,81 \%$, а коефіцієнт пульсацій (THD) - $1,82 \%$. Значення коефіцієнта потужності перетворювального агрегату досягає $95,8 \%$, значення еквівалентної заважаючої напруги перевищує гранично допустиме значення (4 В згідно 3 вимогами [2]) та становить 9,23 В.

Далі проводимо дослідження імітаційної комп'ютерної моделі пасивного фільтра ЗС3, що зображена на рис. 8. Умови моделювання цього фільтра ідентичні описаним вище для моделі, яка зображена на рис. 7.

3 рис. 8 видно, що амплітуди неканонічних гармонік частотами 100 та 200 Гц становлять 1,1 та $0,9 \%$ відносно постійної складової, амплітуда основної гармоніки 300 Гц дорівнює $1,51 \%, \quad \mathrm{a}$ коефіцієнт пульсацій $-2,08 \%$. Значення коефіцієнта потужності перетворювального агрегату досягає $95,8 \%$, однак значення еквівалентної заважаючої напруги перевищує майже у чотири рази гранично допустиме значення і становить $14,86 \mathrm{~B}$.

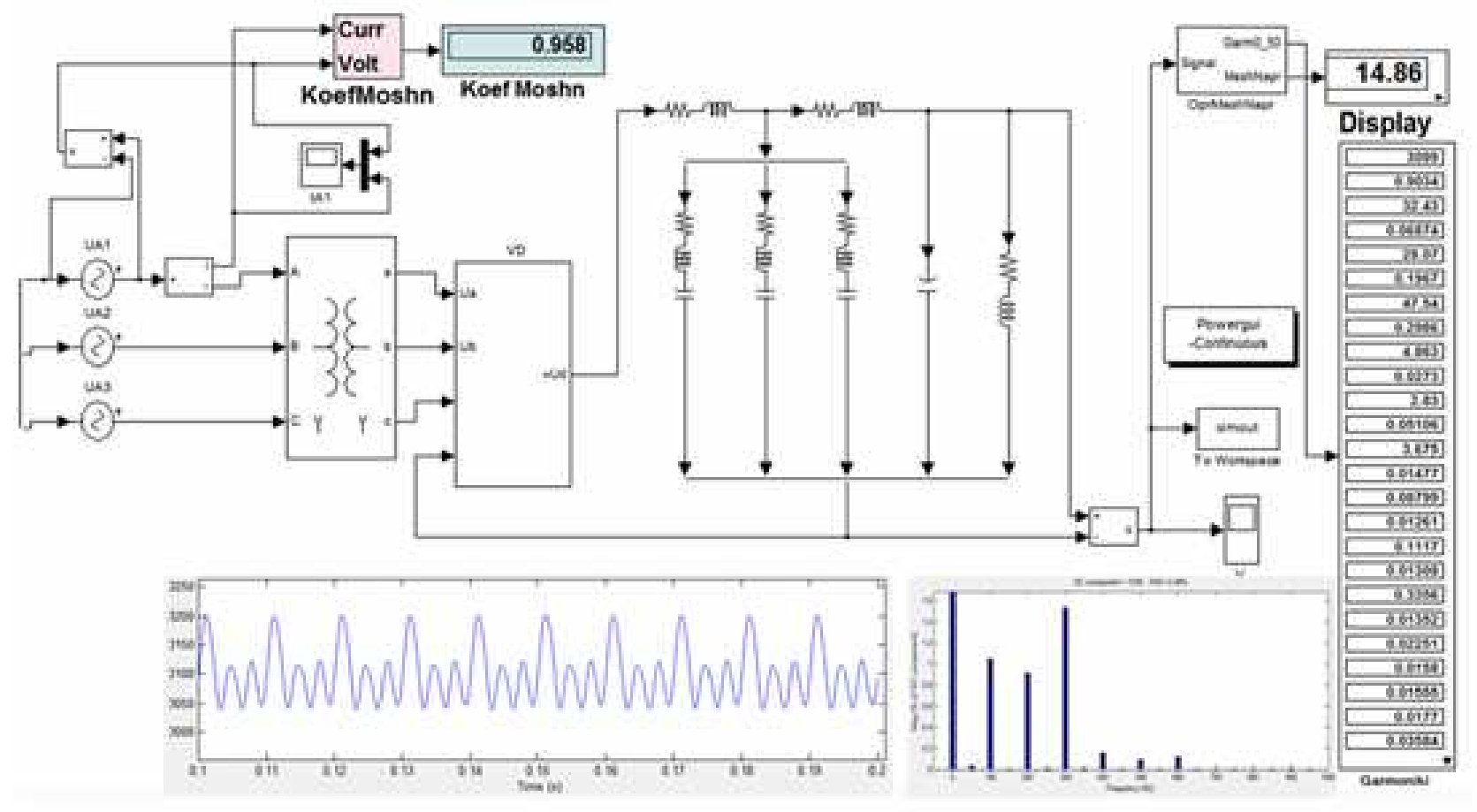

Рис. 8. Імітаційна комп'ютерна модель пасивного фільтра 3С3, осцилограма вихідної напруги та діаграма спектрального складу

Далі проводимо дослідження схеми пасивного фільтра 3С3, комп'ютерна модель якого зображена на рис. 9, умови моделювання ідентичні попереднім.

3 рис. 9 видно, що амплітуди неканонічних гармонік частотами 100, 200 Гц становлять 0,7 та 0,2\% відповідно, амплітуда основної гармоніки вихідної напруги випрямляча 300 Гц дорівнює $1,05 \%$, а THD $1,29 \%$. Значення коефіцієнта потужності перетворювального агрегату досягає $95,81 \%$, однак значення еквівалентної заважаючої напруги перевищує у 2,3 разу гранично допустиме значення і становить $9,29 \mathrm{~B}$.

Надійність та економічність роботи тягової підстанції постійного струму багато у чому залежить від типу обраного випрямляча. Донедавна застосовувались тягові випрямлячі, що були ввімкнені за так званими шестипульсними схемами. Такі схеми мають суттєві недоліки: відносно низький коефіцієнт потужності (до 0,95), спотворену форму струму, що споживається, і значний вплив тягових струмів на повітряні лінії зв'язку та залізничної автоматики. На цей час усе ширше встановлюються на модернізованих або новопобудованих підстанціях дванадцятипульсні випрямні установки, що забезпечують вищу технікоекономічну ефективність тягових підстанцій, порівняно 3 шестипульсними. Дванадцятипульсні випрямлячі дають змогу: збільшити коефіцієнт потужності тягової підстанції до 0,97-0,98; покращити форму кривої струму, що споживається, збільшити якість електричної енергії випрямленої напруги i 
знизити вплив тягової мережі на лінії зв'язку; підвищити рівень напруги у тяговій мережі без застосування спеціальних пристроїв регулювання напруги; знизити витрати електротехнічних матеріалів, що витрачаються на виготовлення випрямляча. Трифазні двомостові схеми випрямлення здебільшого виявляються найбільш економічно доцільними для реалізації потужних випрямних установок тягових підстанцій 3 напівпровідниковими некерованими ключами на діодах.

Далі проводимо дослідження пасивного фільтра для дванадцятипульсних випрямних установок, комп’ютерна модель якої зображена на рис. 10, умови моделювання також ідентичні опису до схеми рис. 7.

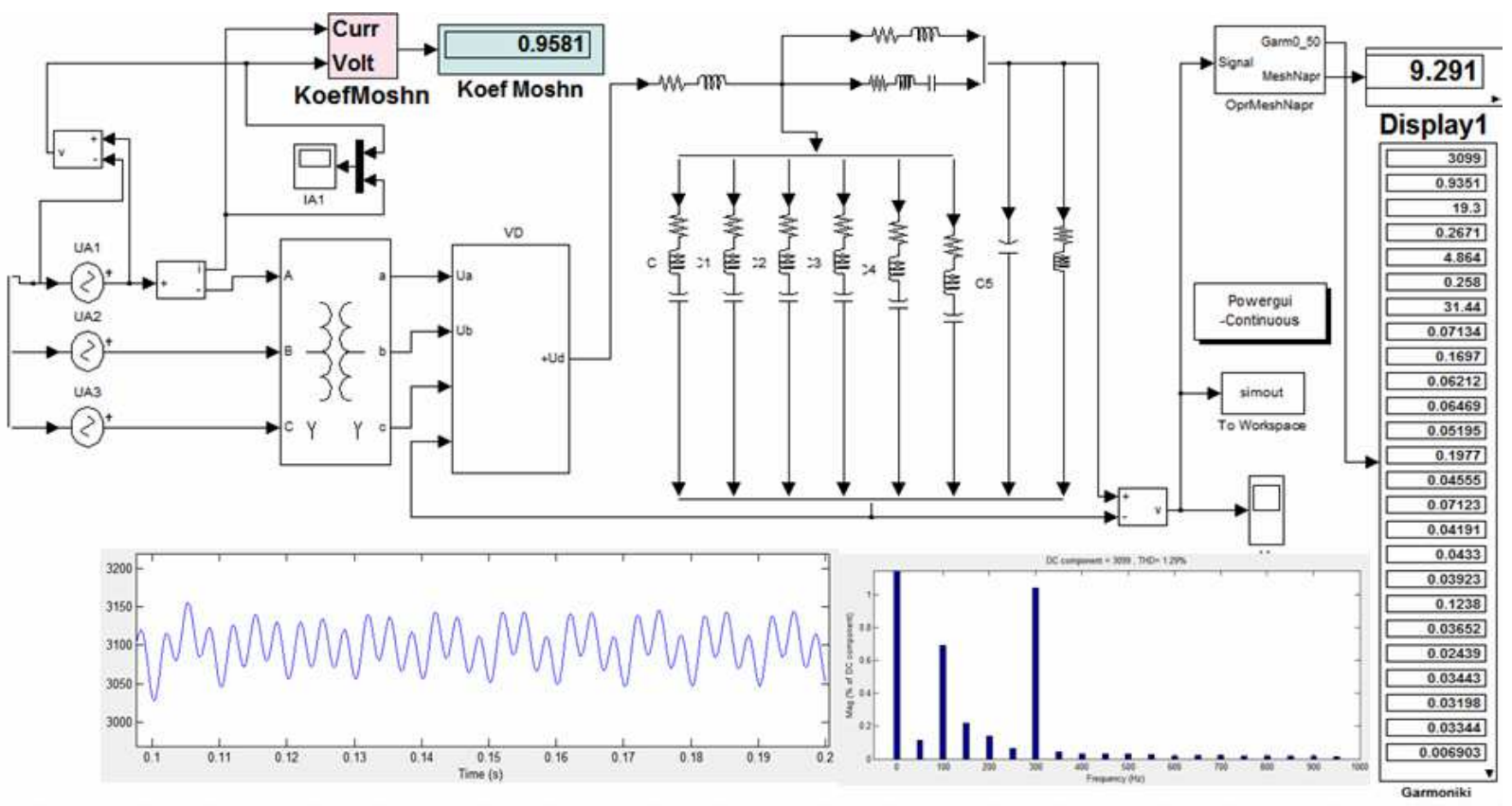

Рис. 9. Імітаційна комп'ютерна модель пасивного фільтра ЦНДІ МШС, та осцилограма вихідної напруги та діаграма спектрального складу

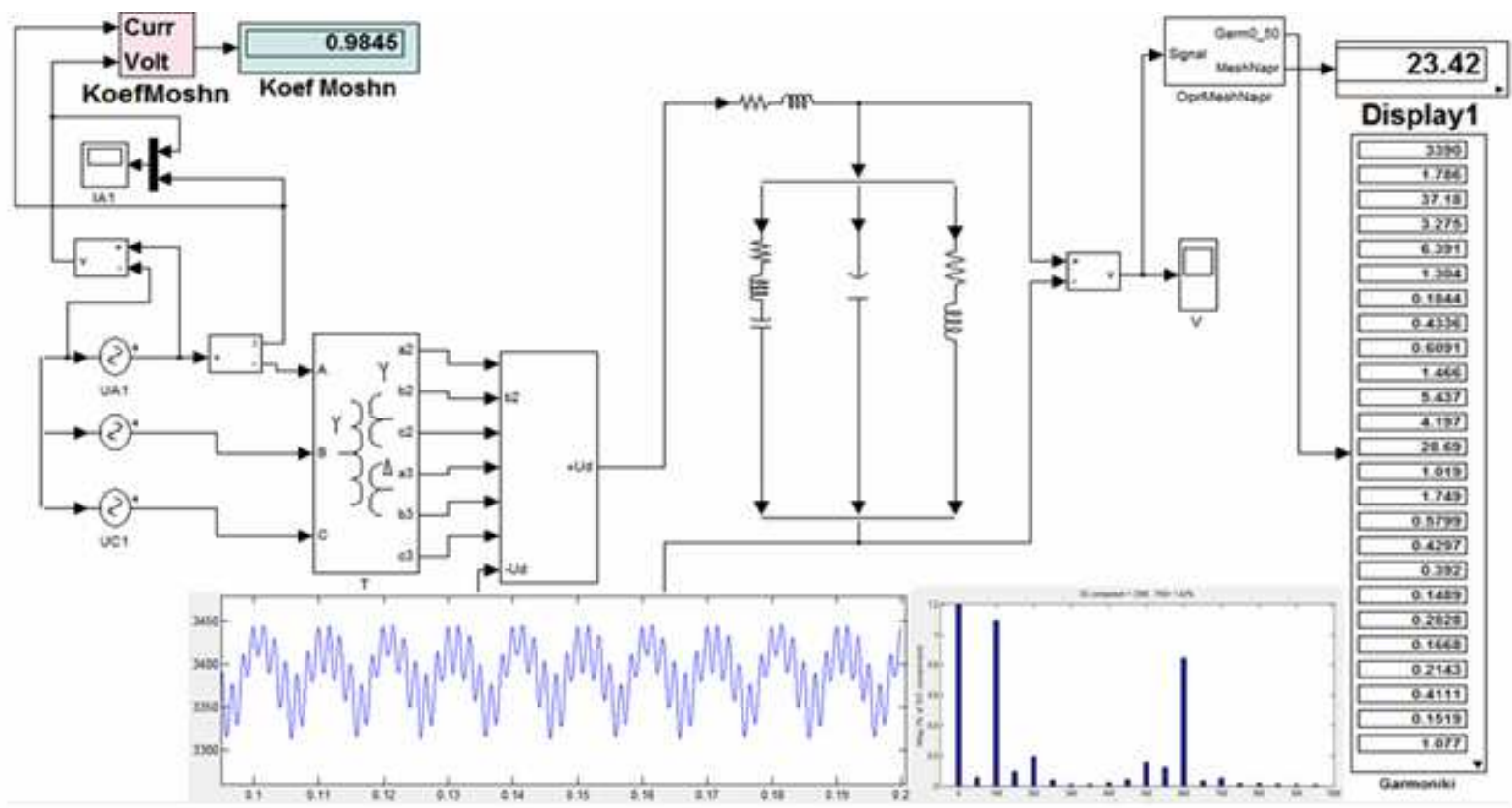

Рис. 10. Імітаційна комп’ютерна модель пасивного фільтра для дванадцятипульсних випрямних установок, осцилограма вихідної напруги та діаграма спектрального складу 
І Н Ф О Р М А Ц Й Н О - КЕ Р У Ю Ч І С И С Т Е МИ Н А З А Л І З Н И Ч Н О М У Т Р А Н С П О Р Т І

3 рис. 10 видно, що амплітуди неканонічних гармонік частотами 100, 200 Гц становлять 1,11 та 0,22\% відповідно, амплітуда основної гармоніки (для дванадцятипульсного випрямляча частотою 600 Гц) дорівнює $0,82 \%$, a THD - 1,42\%. Значення коефіцієнта потужності дванадцятипульсного перетворювального агрегату досягає 98,45\%, еквівалентна заважаюча напруга перевищує майже у шість разів допустиме значення і становить 23,42 В. Тобто лише застосування дванадцятипульсного випрямляча не забезпечує високої якості випрямленої напруги й особливо в умовах несиметрії напруги живлення перетворювального агрегату.

У результаті дослідження згладжувальних пристроїв на імітаційних комп'ютерних моделях було показано, що дійсно при несиметрії вхідної трифазної напруги випрямною установкою генеруються у вихідну напругу гармоніки частотою нижче основної, кратні частоті напруги мережі живлення (100, 200 Гц). На відміну від звичайних (канонічних) гармонік, до яких відносять основну та вищі, кратні частоті мережі живлення, ці гармоніки прийнято називати неканонічними гармоніками. Вони майже не придушуються, а іноді навіть підсилюються пасивним фільтром, тому збільшують коефіцієнт пульсацій вихідної напруги тягової підстанції та створюють значний заважаючий вплив на пристрої зв'язку, сигналізації та автоблокування.

При проведенні НДР «Перевірка електромагнітної сумісності тягової підстанції з контактною мережею» було також установлено, що при значеннях струму навантаження близько номінального та коефіцієнті несиметрії трифазної живильної напруги в межах до $2 \%$, що призводить до зростання амплітуд канонічних i неканонічних гармонік i еквівалентна заважаюча напруга на виході пасивних фільтрів досягає на деяких тягових підстанціях 25-30 В. Таке значне зростання еквівалентної заважаючої напруги пов'язане 3 додатковим фактором - впливом розладу режекторних ланок пасивного фільтра, який відбувається за рахунок погіршення основних характеристик елементів 3 плином часу (у першу чергу конденсаторів).

Ця проблема посилюється при збігові або близькому розташуванні власної частоти аперіодичного $L C$-фільтра та зазначених гармонічних складових, деякі 3 них у такому випадку передаються на вихід підстанції навіть із підсиленням. Щоб таких проблем не виникало, необхідно знижувати резонансну частоту аперіодичного $L C$-фільтра до частот нижче частот неканонічних гармонік та підвищувати добротність ланок пасивного фільтра.

Як показано у роботі [6], економічно недоцільно застосовувати пасивні фільтри для компенсації гармонік 3 частотами нижче основної частоти випрямляча, так як це призводить до значного ускладнення схеми та конструкції, зростання їх маси та габаритних розмірів. Альтернативним рішенням щодо пасивних згладжувальних пристроїв $\epsilon$ застосування активної фільтрації [7-10], яка забезпечує ефективне придушення низькочастотних канонічних i неканонічних гармонік випрямленої напруги.

\section{Висновки}

Проведене аналітичне та імітаційне дослідження процесів у згладжувальних пристроях на тягових підстанціях постійного струму показало, що при допустимих значеннях несиметрії вхідної трифазної напруги виникають низькочастотні неканонічні гармоніки із амплітудами у десятки вольт. Вони практично не придушуються згладжувальними пристроями на основі пасивних фільтрів, у результаті спостерігається збільшення коефіцієнта пульсацій

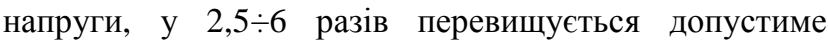
значення інтегрального показника - еквівалентної заважаючої напруги. Це призводить до порушення чинних вимог щодо рівня небезпечних і заважаючих впливів тягової мережі на суміжні електроустановки, якість i втрати енергії в тяговій мережі. Задля запобігання перерахованих недоліків згладжувальних пристроїв, зменшення витрат на їх виготовлення, монтаж та експлуатацію і підвищення ефективності тягового електропостачання постійного струму доцільним $є$ застосування комбінованих активних фільтрів.

\section{Список використаних джерел}

1. Щербак, Я. В. Аналіз роботи пасивних фільтрів тягової підстанції постійного струму [Текст] / Я. В. Щербак, Ю. О. Семененко // Інформаційнокеруючі системи на залізничному транспорті. 2015. - №1(110). - С. 53-57.

2. Семененко, Ю. О. Комбінований активний фільтр послідовного типу 3 імпульсною системою керування при формуванні зворотного зв'язку за струмом навантаження [Текст] / Ю. О. Семененко // Вісник НТУ «ХПІ». - 2015. - № 12(1121). C. $420-424$.

3. Технічне обслуговування та ремонт. Правила [Текст] : ВНД УЗ 32.2.04.047 2014. ЦЕ-0045 : наказ № 441-Ц/од / М-во інфраструктури України, Держадміністрація залізничного транспорту України, Укрзалізниця. - К. : ТОВ Девалта, 2014. 58 с. - (Препринт).

4. Семененко, Ю.О. Підвищення ефективності системи тягового електропостачання постійного струму [Текст] / О. І. Семененко, Ю. О. Семененко // Зб. наук. праць Укр. держ. ун-ту залізнич. трансп. - Харків : УкрдУЗТ, 2015. - Вип. 153. C. 47-54. 
5. Правила улаштування системи тягового електропостачання залізниць України [Текст] : ЦЕ-0009. - К. : ТОВ „Швидкий рух”, 2005. - 80 с.

6. Luo A. Design considerations for maintaining DC side voltage of hybrid active power filter with injection circuit [Text] / A. Luo, Z. Shuai, J. Shen [et. al.] // Power Electronics, IEEE Transactions. - 2009. Vol. 24. - P. 75-84.

7. Ling Su, Dong-yuan Zhao, Jian-ye Chen, Zan-ji Wang. Digital controller for hybrid filter in HVDC based on approximate inverse system. Frontiers Of Electrical And Electronic Engineering In China // Vol. 1. - № 4. - pp. 367-370. - 2005.

8. Heydt, G. T. Second harmonic components in power system voltages and currents [Text] / G.T. Heydt, Y. Liu // IEEE Transactions on Power Delivery, Vol. 20, No. 1, January 2006, P. 521-523.

9. Shcherbak, Y. Analysis of dynamic characteristics of the active filter-stabilizer [Text] / Y. Shcherbak, Y Semenenko, O. Semenenko // Eastern-European Journal of Enterprise Technologies, №2/8(86). - 2017. - P. 10-15.

Семененко А. И., Супрун А. Д., Семененко Ю. А., Ткаченко М. П. Исследование эффективности работы сглаживающих устройств преобразовательных агрегатов тяговых подстанций постоянного тока.

Аннотация. Рассмотрены пути улучшения качества энергии питания электрического подвижного состава постоянного тока. Проведен анализ работы сглаживающих устройств, используемых на тяговых подстанциях для подавления переменной составляющей выходного напряжения. Экспериментально подтверждено, что при несимметрии входного напряжения преобразовательным агрегатом в тяговую сеть генерируются не только канонические гармоники напряжения с частотами основной и высших гармоник, но и неканонические гармоники выпрямленного напряжения. Для их подавления необходимы очень сложные, громоздкие сглаживающие устройства, которые еще и не эффективны на низких частотах.

Ключевые слова: тяговая подстанция, пассивный фильтр, гармонические составляющие, передаточная функция, пульсность выпрямителя, коэффициент сглаживания, частотные характеристики.
Semenenko O. I., Suprun O. D., Semenenko Y. O., Tkachenko M. P. Investigation of the efficiency of smoothing devices converting units traction substations DC.

Abstract. The article considers ways to improve the quality of the energy supply of electric rolling stock of DC railways. An analysis of the work of smoothing devices used in traction substations is performed to compensate for the variable component of the output voltage. In the case of asymmetry of the input voltage of the transformer unit in the traction network, non-canonical harmonic components of the output voltage of the traction substation of a direct current are generated, for their suppression, too cumbersome smoothing devices are required. The study of smoothing devices was carried out on simulation computer models and it was found that in the case of asymmetry of input voltages by the rectifier unit, it is generated in the output voltage of the harmonics at a frequency lower than the main, frequency of the supply network, which is called the non-canonical harmonics of the variable component of the output voltage of the traction substation. They are not suppressed by any passive filter, in addition, the voltage pulsation factor increases and creates a significant interfering effect on the device of the automatic locking system. To avoid such problems, it is necessary to reduce the resonance frequency of the LS-filter to the necessary value, which excludes the enhancing properties of the smoothing device at frequencies of the harmonic components in the range of non-canonical harmonics.

Keywords: traction substation, passive filter, harmonic components, transfer function, rectifier pulsation, smoothing factor, frequency characteristics.

Надійшла 16.10.2018 p.

Семененко Олександр Іванович, доцент кафедри електроенергетики, електротехніки та електромеханіки Украйнського держсавного університету залізничного транспорту, к.т.н., доиент. E-mail: semenoi@i.ua ORCID: https://orcid.org/0000-0001-8885-6783

Супрун Олександр Данилович, дочент кафедри електроенергетики, електротехніки та електромеханіки Украӥнського державного університету залізничного транспорту, к.т.н., доиент. E-mail: adsup@ukr.net ORCID: https://orcid.org/0000-0002-8732-7609

Семененко Юрій Олександрович, старший викладач кафедри електроенергетики, електротехніки та електромеханіки Українського державного університету залізничного транспорту, к.т.н. E-mail: slider2012@i.ua ORCID: https://orcid.org/0000-00019422-3528

Ткаченко Максим Петрович, магістрант кафедри електроенергетики, електротехніки та 
І Н Ф О Р М А І Й Н О - К Е Р У Ю Ч І С И С Т М И Н А 3 А Л І 3 Н И Ч Н О М У Т Р А Н П О Р Т І

електромеханіки Українського державного університету залізничного транспорту. E-mail: makson.tkachenko@gmail.com ORCID: https://orcid.org/0000-0002-5920-7773

Semenenko Oleksandr Ivanovyvch, Associate Professor, chair of electric power industry, electrical engineering and electromechanics, Ukrainian State University of Railway Transport, Ph.D., assistant professor. E-mail:semenoi@i.ua ORCID: https://orcid.org/00000001-8885-6783

Suprun Oleksandr Danylovych, Associate Professor, chair of electric power industry, electrical engineering and electromechanics, Ukrainian State University of Railway Transport, Ph.D., assistant professor. E-mail: adsup@ukr.net ORCID: https://orcid.org/0000-00028732-7609

Semenenko Yurii Oleksandrovivch, Senior Lecturer, chair of electric power industry, electrical engineering and electromechanics,Ukrainian State University of Railway Transport, Ph.D. E-mail: slider2012@i.ua ORCID: https://orcid.org/0000-0001-9422-3528

Tkachenko Maksym Petrovych, graduate students, chair of electric power industry, electrical engineering and electromechanics, Ukrainian State University of Railway Transport. E-mail: $\quad$ makson.tkachenko@gmail.com ORCID: https://orcid.org/0000-0002-5920-7773 